\title{
Long-term mark-recapture monitoring of a Colorado pikeminnow Ptychocheilus lucius population: assessing recovery progress using demographic trends
}

\author{
Douglas B. Osmundson ${ }^{1,3, *}$, Gary C. White ${ }^{2}$ \\ ${ }^{1}$ Colorado River Fishery Project, US Fish and Wildlife Service, 445 West Gunnison Ave., Suite 140, Grand Junction, \\ CO 81505, USA \\ ${ }^{2}$ Department of Fish, Wildlife, and Conservation Biology, Colorado State University, 1484 Campus Delivery, Fort Collins, \\ CO 80523, USA \\ ${ }^{3}$ Present address: 38034 Road, Palisade, CO 81526, USA
}

\begin{abstract}
Colorado pikeminnow Ptychocheilus lucius, a large, endangered, piscivorous cyprinid once abundant throughout warm-water reaches of North America's Colorado River system, has been reduced to 2 wild populations inhabiting the Colorado and Green rivers. Status and trends of these remaining populations were unknown when a recovery program was initiated in 1987. During 1991 to 2013, we used mark-recapture to monitor the smaller Colorado River population. Adult abundance was estimated and patterns of recruitment and dispersal assessed to determine if recovery actions produced a population response. In 1992, adults were rare $(\hat{N}=345$; $95 \% \mathrm{CI}=216$ to 583 ) in the $288 \mathrm{~km}$ study area, but recruitment of a strong 1986 year class began a positive trend, and adult estimates reached $674(95 \% \mathrm{CI}=517$ to 897$)$ by 2008 . A significant decline then ensued, and by 2013, an estimated 282 adults remained (95\% CI $=204$ to 407). Annual adult survival was relatively high and stable. Juvenile survival was variable, making catch rates of young-of-the-year unreliable predictors of later recruitment strength. An estimated average of 6.5 fish immigrated annually to the Colorado River from the larger Green River population, and movements appeared balanced in direction. Though self-sustaining over the $23 \mathrm{yr}$ study, low abundance and a recent rapid decline suggest long-term population persistence is tenuous. Population increase is impeded by a high frequency of weak recruiting cohorts. Results suggest $25 \mathrm{yr}$ of recovery efforts have not sufficiently addressed ongoing threats affecting recruitment, including river regulation, non-native fish invasions, and other potential threats yet to be evaluated.
\end{abstract}

KEY WORDS: Riverine fish · Endangered species · Mark-recapture $\cdot$ Monitoring $\cdot$ Recovery $\cdot$ River regulation $\cdot$ Ptychocheilus lucius $\cdot$ Colorado River $\cdot$ Colorado pikeminnow

\section{INTRODUCTION}

Understanding population dynamics of long-lived endangered species requires long-term monitoring. Those species exhibiting sporadic recruitment, or periodic strategists (e.g. Winemiller 2005), require especially long periods before trends in abundance can be assessed (Pine et al. 2001). Paradoxically, rarity of endangered species often makes obtaining

${ }^{*}$ Corresponding author: doug_osmundson@fws.gov accurate demographic information difficult (MacKenzie et al. 2005). For migratory species, influences of neighboring populations may affect demographics and viability; hence, the degree of linkage among populations must also be known (Carroll et al. 1996). For populations of long-lived aquatic species with dispersed individuals, long-term information gathering is especially challenging and requires a large commitment of resources (Pine et al. 2001, Al-

(C) The authors and, outside the USA, the US Government 2017. Open Access under Creative Commons by Attribution Licence. Use, distribution and reproduction are unrestricted. Authors and original publication must be credited.

Publisher: Inter-Research · www.int-res.com 
Chokhachy et al. 2009), making such long-term time series data rare (Gerber et al. 1999). However, without such data, the degree of vulnerability to extirpation cannot be reliably estimated (Fieberg \& Ellner 2000). Mark-recapture studies, where feasible, can reveal much about a population in decline including adult abundance, survival rate, dispersal, recruitment, and population trend (Gerber et al. 1999). More importantly, obtaining such information can reveal which key demographic parameter is impeding population increase, a first step toward identifying causes of decline (McMahon et al. 2005) and thus opportunities for enabling recovery.

Freshwater fish species have declined in many parts of the world from overfishing, pollution, physical or biotic habitat alteration, or some combination thereof (Galat \& Zweimüller 2001, Budy \& Schaller 2007, Jelks et al. 2008, Castello et al. 2015). For exploited species, overharvest may be an obvious cause of decline; for others, difficulty identifying causal agents greatly hampers development of restoration strategies (McAdam 2011). In such cases, understanding factors driving population declines requires linking knowledge of life history attributes, population dynamics, and environmental change (Cooke et al. 2012).

In 1991, we began using mark-recapture techniques to monitor 1 of 2 remaining wild populations of the endangered Colorado pikeminnow Ptychocheilus lucius of North America's Colorado River. Prior use of mark-recapture in fisheries research was often restricted to closed systems (ponds, lakes, blocked stream sections), and studies were generally short lived due to tag loss problems (Pine et al. 2003). The adoption of the passive integrated transponder (PIT) tag as a means to permanently and safely mark fish with a unique identifier allowed long-term capture history data collection for long-lived aquatic organisms (Gibbons \& Andrews 2004). After $23 \mathrm{yr}$ of such monitoring, our findings should be instructive not only to those charged with preserving $P$. lucius but also for others similarly engaged in monitoring and conservation of imperiled long-lived fishes in other systems.

The Colorado River population is small but so far has been self-sustaining (Osmundson \& Burnham 1998, Osmundson et al. 2000). Adult monitoring began in the mid-1980s using electrofishing catch per effort (CPE) indices. In 1987, an interagency recovery program was formed to allocate funding and prioritize research and management efforts. We initiated markrecapture studies to more accurately assess whether recovery actions produced a population response.
Our objectives were to (1) provide estimates of abundance and adult survival rate, (2) describe patterns of dispersal and recruitment, (3) determine whether fall young-of-the-year (YOY) densities provide a reliable index to year-class strength and later recruitment, and (4) determine the level of connectedness between Green and Colorado river populations. We also report here results of 2 recovery actions, fish stocking and fish passage. Recruitment limitations, previous recovery actions, and efficacy of mark-recapture studies of endangered fishes in large rivers are discussed in light of our findings.

\section{General history of species decline}

Colorado pikeminnow was 1 of 22 fish species originally listed as endangered under the 1966 Endangered Species Protection Act (Wilcove \& McMillan 2005). Three Ptychocheilus congeners inhabit rivers of the Pacific Northwest, but only P. lucius is listed as federally endangered. All species are fluvial specialists dependent on swift water for reproduction. Colorado pikeminnow, endemic to warm-water reaches of the Colorado River basin since perhaps the middle Pliocene (Miller 1958), were abundant through the mid-1930s from Wyoming to the Gulf of California. Historically attaining lengths of $1.8 \mathrm{~m}$ (Miller 1961), North America's largest cyprinid was the top piscivore of the Colorado River (Moyle 1976); today, the largest individuals are about half this length and about 40 yr old (Osmundson 2006). Habitat alteration and non-native fish invasions associated with dam building in the 1930s to 1960s rendered the entire lower Colorado River basin uninhabitable (Minckley 1973), with the last specimen captured in 1975 (Smith et al. 1979, Mueller \& Marsh 2002). Today, populations are restricted to 3 upper basin (upstream of Lee's Ferry, Arizona) river systems (Holden \& Stalnaker 1975, Ryden \& Ahlm 1996, Osmundson \& Burnham 1998, Bestgen et al. 2007). Even there, dams and diversions have reduced their range by $34 \%$ (Osmundson 2011).

In the upper basin, the San Juan River population collapsed after reservoirs constructed in the 1960s inundated productive upstream adult feeding areas and critical downstream nursery areas and severely altered the hydrograph (Koster 1960, Holden 2000). A few wild adults were captured through the 1990s (Platania et al. 1991, Ryden \& Ahlm 1996), with the last captured in 2000 (Ryden 2003). Attempts to reestablish a population through stocking have been partially successful, with some survival and repro- 
duction reported, but self-sustainability has proved elusive (Durst \& Franssen 2014).

In contrast, the mainstem Green River, along with 2 major tributaries, the White and Yampa rivers, currently supports the largest remaining population. Two major spawning reaches and 2 nursery reaches exist (Tyus 1991, Bestgen \& Hill 2016). An initial abundance estimate from mark-recapture sampling, begun in 2000, was 4084 fish $>450 \mathrm{~mm}$ total length (TL) (Bestgen et al. 2007). After a general decline, estimates from 2011 to 2013 averaged about half this number (Bestgen et al. 2017). River regulation effects and nonnative fish invasions threaten the Green River population (Johnson et al. 2008, Bestgen \& Hill 2016).

In the upper Colorado River system (CRS), thermally suitable reaches extend $342 \mathrm{~km}, 36 \%$ that in the Green River system (GRS) (952 km). Two primary tributaries, the Gunnison and Dolores rivers, once supported adults and perhaps other life stages, but habitat suitability declined from flow regulation, trans-basin diversions, and reduced temperatures from upstream dams (Osmundson 2011). In the mainstem, spawning aggregations are small and locations vary with conditions (McAda \& Kaeding 1991). The one primary nursery area is located at the lower end of our study area. Flow regulation has been substantial: mean magnitude of spring peak flows (mean flow on the year's highest day) was $52 \%$ that of pre-development conditions, compared to $80 \%$ in the middle Green River (Osmundson \& Kaeding 1991).

The species is classified as endangered under the Endangered Species Act (39 FR 1175). Criteria for downlisting to threatened status include Green and Colorado river populations to be self-sustaining and each abundance point estimate within a 5 yr monitoring period to exceed 2600 (Green River sub-basin) and 700 (Colorado River sub-basin) adults. In addition, 1000 individuals $>300 \mathrm{~mm} \mathrm{TL}$, either wild or stocked, must be established in the San Juan sub-basin (USFWS 2002). The current IUCN Red List of Threatened Species (version 2016-1) classifies $P$. lucius as Vulnerable with a stable trend (www.iucnredlist.org/details/ 18829/0?2600).

\section{MATERIALS AND METHODS}

\section{Study area}

Sampling was conducted throughout warm-water reaches of the Colorado River upstream of the Green River confluence (Fig. 1). Locations are provided as distance (river kilometers ([rkm]) upstream of this confluence. The study area was partitioned into 2 reaches separated by $19 \mathrm{~km}$ Westwater Canyon (not sampled). The lower reach (rkm 0 to 181) remained constant, but the extent of the upper reach changed. From 1991 to 2005, the upper reach extended from rkm 201 to the base of the Price Stubb Dam (rkm $303)$. In early 2008 , the dam was removed to facilitate passage, extending the study area upstream to a second diversion dam (rkm 312). There, a fish ladder and trap built in 2005 allowed monitoring of fish

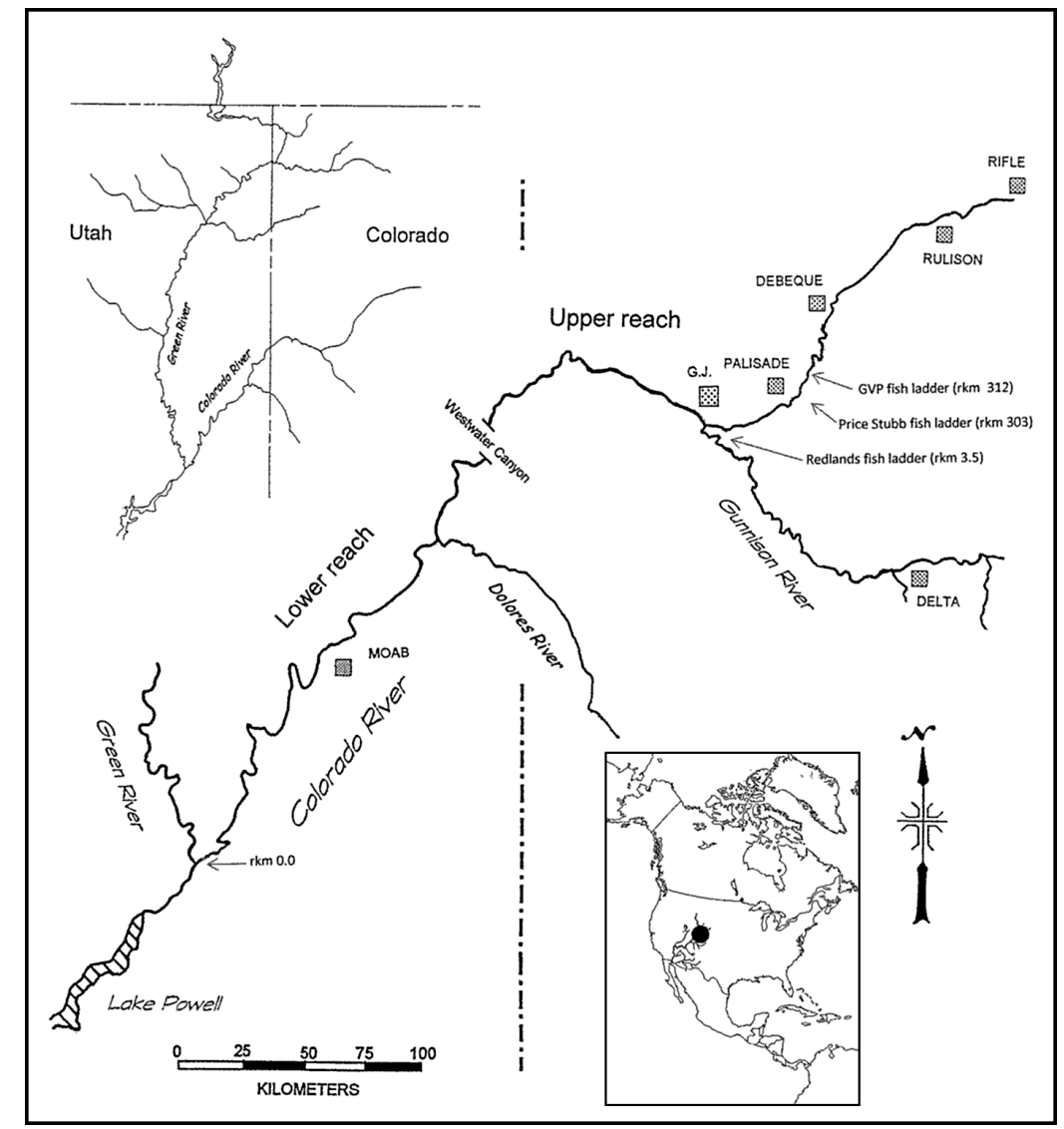

Fig. 1. Upper and lower reaches of the Colorado River study area. The lowerreach downstream boundary was the confluence with the Green River (river kilometer [rkm] 0.0); the upstream boundary was the lower end of Westwater Canyon (rkm 181). The upper-reach downstream boundary was the upper end of Westwater Canyon (rkm 201); the upstream boundaries were the diversion dams at rkm 303 (1991 to 2005) and rkm 312 (2008 to 2013) on the Colorado River and the Redlands Diversion Dam at rkm 3.5 on the Gunnison River (all years). G.J.: Grand Junction; GVP: Grand Valley Project (diversion dam) 
attempting to pass upstream. No verified capture records exist of Colorado pikeminnow upstream of this diversion, currently or historically. Similarly, Colorado River fish had access to the lowermost $3.5 \mathrm{~km}$ of the Gunnison River (at Colorado rkm 275), with additional upstream movement blocked by the Redlands Diversion Dam. In 1996, a fish ladder and trap were built there, allowing monitoring of upstream passage. The upper-reach study area included the short Gunnison River reach below the dam.

Mean discharge during 1991 to 2013 at the Colorado-Utah state line (US Geological Survey gage 09163500), downstream of the Gunnison river inflow, was $158 \mathrm{~m}^{3} \mathrm{~s}^{-1}$ in April, $371 \mathrm{~m}^{3} \mathrm{~s}^{-1}$ in May, and $414 \mathrm{~m}^{3}$ $\mathrm{s}^{-1}$ in June. Annual peak flows (mean on highest day) ranged from 156 to $1396 \mathrm{~m}^{3} \mathrm{~s}^{-1}$ and generally occurred from late May to mid-June.

\section{Fish sampling}

Our multiple-pass, mark-recapture sampling regimen followed the robust design (Pollock 1982, Pollock et al. 1990). Closely grouped sampling periods (passes) within years allowed estimation of annual population abundance using closed models, while multiple sampling years allowed survival rate estimation using open models.

Trammel netting and electrofishing were used to capture Colorado pikeminnow $\geq 250 \mathrm{~mm}$ long, as previously described by Osmundson \& Burnham (1998). Trammel netting was primarily used during 1991 to 2000 and electrofishing during 2003 to 2013. An initial 4 yr sampling period was followed by a 3 yr non-sampling period intended to give fish some respite from capture and handling. After that, sampling followed a 3 yr on, 2 yr off regimen.

Beginning in April, trammel nets were set in lowvelocity, off-channel habitats used by many subadults and adults during spring runoff, when flows increase dramatically (Osmundson \& Kaeding 1991). Every backwater deep enough to allow boat entry $(>0.5 \mathrm{~m})$ was netted.

Through 2000, all sampling was done by one 2-person crew, and electrofishing was restricted to those reaches containing few backwaters. When electrofishing, both shorelines were sampled in a downstream direction using a $5 \mathrm{~m}$ long craft, either a hardbottomed jon boat or an inflatable raft. Beginning in 2003, we increased effort: 2 crews worked the upper reach, while 2 others worked the lower reach. Sampling passes generally took $9 \mathrm{~d}$ for the upper reach and $11 \mathrm{~d}$ for the lower reach. Fish were measured for maximum TL (Anderson \& Gutreuter 1983), weighed (nearest gram), and electronically scanned for a PIT tag. PIT tags were implanted internally with a hypodermic needle inserted 2 to $5 \mathrm{~mm}$ posterior to the base of the left pelvic fin. The goal was to complete 4 to 5 passes annually, but the actual number depended on flow conditions, which affected spawning initiation. Sampling was curtailed with the onset of spawning migrations, usually in mid- to late June.

\section{Analyses}

Abundance and survival rate estimation

A capture history matrix was used as input to Program MARK (White \& Burnham 1999), with each row representing a unique fish, and columns representing individual sampling passes with capture (or noncapture), length at capture, and capture reach indicated. After 2005, capture data could not be added to the matrix because the PIT tag type $(400 \mathrm{kHz})$ and tag readers we initially used were discontinued by the manufacturer. The new, updated readers were incapable of detecting some of the earlier tags. This meant many early fish in the matrix could not be recaptured, biasing aspects of model output. We therefore began building a second matrix starting with data from 2004, the year new tags (134 kHz) and readers were first employed. During 2004 and 2005, fish were scanned with both types of readers. This allowed the periods covered by the 2 matrices to overlap. Because first and last annual abundance estimates are generally the most biased, the 2 yr overlap allowed dropping the last estimate (2005) from the first analysis and the first estimate (2004) from the second analysis. Hence, 1991 to 2004 abundance estimates were derived from the first matrix; 2005 to 2013 estimates, from the second.

The closed robust-design multi-state (2 reaches) model (White et al. 2006) examined numerous models containing various combinations of covariates used to estimate survival $(S)$, transition probability (movement between reaches), and initial probability of capture $(p)$. Primary covariates included reach, fish length, and time (year and pass). In the first analysis (1991 to 2005), models of $p$ were considered that included flow level, water temperature, and number of boat days for each pass. Because none of those models explained temporal variation in $p$, they were not considered in the later analysis. Although $p$ might be affected by variation in effort, or shocking or trammel netting efficiency, models take $p$ into account when 
calculating estimates of abundance and survival. Thirty-three models were examined using the 1991 to 2005 capture data; 13 models, using the 2004 to 2013 data (Table S1 in the Supplement at www.intres.com/articles/suppl/n034p131_supp.pdf). Annual survival rates were estimated using model averaging following Bestgen et al. (2007).

To use fish length as a covariate, lengths for each captured fish were needed for each study year. The von Bertalanffy model was fitted to measured lengths to estimate lengths in years when individuals were not captured. To fit the model, a difference equation was assumed, following generally the procedures of White \& Brisbin (1980):

$$
L_{i+1}=\left(t_{i+1}-t_{i}\right) k\left(L_{\infty}-L_{i}\right)+L_{i}
$$

where $L_{i}$ is the length at year $i, t_{i}$ is the actual year of the observation, $k$ is the von Bertalanffy growth coefficient, and $L_{\infty}$ is the asymptotic length. To estimate the 2 parameters, the equation was implemented recursively, $t_{i+1}+t_{i}=1$. Using these lengths, an input file for Program MARK was created.

Population size $(N)$ was estimated with the Huggins (1989, 1991) estimator and constructed using model averaging with model weights from the combined analyses. Abundance estimates $(\hat{N})$ were obtained for 3 size classes: $\geq 250 \mathrm{~mm}$ TL (all sampled fish), $\geq 500 \mathrm{~mm}$ TL (adults, assuming a minimum adult length of $476 \mathrm{~mm}$ for most males and $525 \mathrm{~mm}$ for most females; Osmundson 2006), and $\geq 250$ but $<450 \mathrm{~mm}$ TL (juveniles). Confidence intervals for $\hat{N}$ were computed using lognormal transformation of the estimated number of fish never captured $\left(\hat{f}_{0}\right)$, with the number of fish captured $\left(M_{t+1}\right)$ added. Reach-specific estimates of $N$ were summed to provide annual estimates for the entire study area. Variance around summed estimates was calculated by the delta method (Seber 1982), with covariances included in the estimate. Non-overlap of confidence intervals was used to detect statistically significant $(p<0.05)$ differences in estimates of $N$, a method considered conservative (Schenker \& Gentleman 2001). Coefficient of variation $(\mathrm{CV}: 100 \times \mathrm{SE} / \hat{N})$ was used as a measure of estimate precision.

Trends in abundance were assessed using a weighted regression technique following Bestgen et al. (2010). Estimates from variance-covariance matrices produced from Program MARK were used as weights for abundance estimates to address uncertainty (sampling covariances) around each point estimate. Corrected Akaike's information criterion $\left(\mathrm{AIC}_{\mathrm{c}}\right)$ model selection (Akaike 1973) and weights were used to assess level of support for each of 3 competing models. The model with greatest weight was interpreted as best describing the trend. The interceptonly model would indicate no substantial change in abundance (a stable population); the linear model, abundance likely increased or decreased; the quadratic model, an increase was followed by a decrease, or vice versa.

\section{Length frequency}

Length-frequency histograms were used to interpret upstream dispersal and recruitment history. Fish lengths were partitioned into $10 \mathrm{~mm}$ categories and grouped by capture reach.

Relative year-class strength

Relative abundance of young individuals (ages 4 to 7) was used to gauge cohort strength. As Colorado pikeminnow grow beyond age 5 , it becomes increasingly difficult to assign age using length. Relative abundance of age 5 individuals in annual lowerreach length frequencies was therefore used as a surrogate for recruitment strength, with the assumption that many fish surviving to age 5 would also survive to maturity (ages 6 to 10; Osmundson 2006). Individuals were deemed age 5 if their lengths corresponded to those expected for this age. A length-atage curve for ages 0 to 7 was constructed from various data sources (Fig. 2, Table S2 in the Supplement). One of 3 qualitative strength categories was assigned to each year class based on the relative contribution that estimated age 5 individuals made to all lengths sampled (weak: 0 to $15 \%$; moderately strong: 16 to $50 \%$; strong: 51 to $100 \%$ ). In non-sampling years, strength was estimated from relative abundance of age 4 fish in the preceding sampled year or of age 6 or age 7 fish in a subsequent sampled year.

Year-class strength at age 5 and at age 0

To test whether year-class strength at age 0 was a good predictor of later strength at age 5, estimates of age 5 strength were compared to those of the same year class as measured from fall YOY seine surveys 5 yr prior. Densities of YOY, when 2 to 4 mo old, have been monitored since 1982 using a systematic seining protocol (McAda et al. 1994). These CPE data were made available for our use by the Utah Division of Wildlife Resources (UDWR). We assigned 1 of 3 


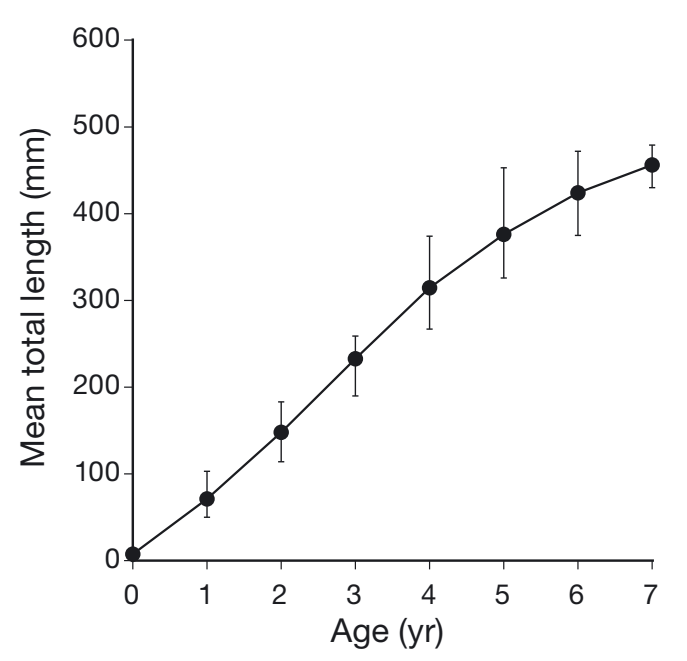

Fig. 2. Age-length relationship of Colorado pikeminnow as derived from various empirical studies. Bars are sample ranges in length. Length at hatching (age 0) from Snyder (1981), age 1 from measured lengths of fish seined near river kilometer 87 in June 1989, age 2 from lower-reach fish captured June 2013 and assumed age 2, and ages 3 to 7 from measurements of fish aged using scales (see Osmundson et al. 1997). Eggs hatch June to August, so lengths provided are at approximately 1 yr intervals from hatching

strength categories to each age 0 cohort based on mean annual CPE (Harding et al. 2013). Categories for YOY were (1) weak: <2 YOY per $100 \mathrm{~m}^{2}$, (2) moderately strong: $\geq 2$ and $<9$ YOY per $100 \mathrm{~m}^{2}$, and (3) strong: $\geq 9$ YOY per $100 \mathrm{~m}^{2}$. The non-parametric Fisher's exact test was used to compare the 23 assigned strengths at age 0 with strengths at later stages (ages 4 to 7). The null hypothesis was that later yearclass strength was independent of strength at age 0 .

\section{Intersystem movements}

Number of movements of marked Colorado pikeminnow between the Colorado and Green river systems was tabulated by querying the PIT tag database maintained by the Upper Colorado River Endangered Fish Recovery Program (Recovery Program).

\section{RESULTS}

\section{Capture summary}

We generated 13 annual estimates of river-wide abundance over a $22 \mathrm{yr}$ period, plus a 1991 upperreach-only estimate. Each capture matrix included data from 20 lower-reach sampling passes and 28 upper-reach sampling passes. Within reaches, 11 to 50 captures were made per pass (Table S3 in the Supplement). During 1991 to 2004, 1034 unique individuals were captured: 547 from the lower reach and 487 from the upper reach. During 2005 to 2013, 637 unique fish were captured: 397 from the lower reach and 240 from the upper reach. Some fish tagged in the earlier period were retagged and treated as new encounters in the second matrix.

\section{Model selection}

The top model (minimum $\mathrm{AIC}_{\mathrm{c}}$ ) for 1992 to 2005 data had an $\mathrm{AIC}_{\mathrm{c}}$ weight of 0.41 . For 2004 to 2013 data, weight of the top model was 0.87 . Both top models included reach and fish length effects on survival but no time effect (survival assumed constant across years). Both also had initial capture probabilities that were reach, time (both year and pass), and fish length specific. Transitions between reaches were reach and length specific for both periods and year specific for the earlier data but not for the more recent data. Due to sparse transition data, estimated transition rates were not informative and therefore not reported here (provided in Table S4 in the Supplement).

\section{Capture probability}

Estimated capture probabilities $(\hat{p})$ standardized for fish $500 \mathrm{~mm}$ TL were highly variable between reaches within years and within reaches among passes and years (Table 1). Mean $\hat{p}$ for passes 1 and 2 (0.06 to 0.07) were similar between reaches. Passes with $\hat{p} \geq 0.10$ mostly occurred from 1993 to 2003 .

\section{Survival rate}

Because each top model indicated no time effect on survival rate, estimates of survival $(\hat{S})$ are considered constant within each matrix period (i.e. no annual estimates of $\hat{S}$ were made). During 1992 to $2005, \hat{S}$ for $500 \mathrm{~mm}$ long fish was significantly higher in the upper reach $(90 \%$; $95 \%$ CI: 87 to $92 \%)$ than in the lower reach (80\%; $95 \%$ CI: 75 to $84 \%$ ). During 2004 to 2013 , $\hat{S}$ was again higher in the upper reach $(86 \% ; 95 \% \mathrm{CI}$ : 77 to $91 \%)$ than in the lower reach $(78 \% ; 95 \%$ CI: 72 to $83 \%$ ) but not significantly. Differences in $\hat{S}$ between earlier and later periods were not significant. 
Table 1. Estimated probability of capture $(\hat{p})$ for Colorado pikeminnow in the lower and upper study reaches, 1991 to 2013. Probabilities are for secondary (passes) and primary (all) capture occasions. Probabilities are standardized for fish $=500 \mathrm{~mm}$ total length because the top model of each capture matrix indicated a length effect. Dashes indicate that no sampling was done. No means were calculated for passes 3,4 , and 5

\begin{tabular}{|c|c|c|c|c|c|c|c|c|c|c|c|c|}
\hline \multirow{2}{*}{ Year } & \multicolumn{6}{|c|}{ - Lower-reach pass } & \multicolumn{6}{|c|}{ Upper-reach pass } \\
\hline & 1 & 2 & 3 & 4 & 5 & All & 1 & 2 & 3 & 4 & 5 & All \\
\hline 1991 & - & - & - & - & - & - & 0.087 & 0.067 & 0.099 & - & - & 0.233 \\
\hline 1992 & 0.045 & 0.037 & - & - & - & 0.080 & 0.061 & 0.070 & 0.067 & - & - & 0.185 \\
\hline 1993 & 0.091 & 0.073 & - & - & - & 0.157 & 0.104 & 0.108 & 0.115 & - & - & 0.293 \\
\hline 1994 & 0.104 & 0.049 & - & - & - & 0.148 & 0.066 & 0.088 & 0.090 & - & - & 0.225 \\
\hline 1998 & 0.087 & 0.170 & - & - & - & 0.242 & 0.091 & 0.143 & 0.107 & - & - & 0.304 \\
\hline 1999 & 0.100 & 0.065 & - & - & - & 0.159 & 0.105 & 0.132 & 0.109 & - & - & 0.308 \\
\hline 2000 & 0.068 & 0.039 & - & - & - & 0.104 & 0.105 & 0.107 & 0.057 & - & - & 0.246 \\
\hline 2003 & 0.011 & 0.017 & 0.043 & 0.041 & - & 0.108 & 0.027 & 0.037 & 0.039 & 0.027 & - & 0.124 \\
\hline 2004 & 0.043 & 0.055 & 0.043 & - & - & 0.135 & 0.047 & 0.040 & 0.119 & - & - & 0.194 \\
\hline 2005 & 0.041 & 0.078 & 0.074 & 0.056 & 0.055 & 0.270 & 0.036 & 0.051 & 0.043 & 0.076 & 0.061 & 0.240 \\
\hline 2008 & 0.033 & 0.074 & 0.089 & 0.058 & - & 0.232 & 0.031 & 0.027 & 0.031 & 0.036 & 0.029 & 0.144 \\
\hline 2009 & 0.029 & 0.090 & 0.078 & 0.055 & - & 0.231 & 0.025 & 0.030 & 0.082 & 0.038 & 0.058 & 0.213 \\
\hline 2010 & 0.058 & 0.043 & 0.098 & 0.119 & - & 0.283 & 0.035 & 0.048 & 0.038 & 0.053 & 0.043 & 0.199 \\
\hline 2013 & 0.035 & 0.064 & 0.058 & - & - & 0.149 & 0.047 & 0.034 & 0.041 & 0.060 & 0.041 & 0.204 \\
\hline Mean & 0.057 & 0.066 & & & & 0.177 & 0.062 & 0.070 & 0.074 & & & 0.222 \\
\hline $\mathrm{SE}$ & 0.008 & 0.010 & & & & 0.019 & 0.008 & 0.010 & 0.009 & & & 0.015 \\
\hline
\end{tabular}

\section{Population size}

Annual summed estimates of abundance (N̂) for all fish ( $\geq 250 \mathrm{~mm} \mathrm{TL}$ ) ranged from 612 to 1577 (Table S5 in the Supplement). Lower-reach juvenile (250 to $449 \mathrm{~mm}$ TL) $\hat{N}$ ranged from 49 to 933 . Juveniles were rare in the upper reach through $2010(\hat{N}=0$ to 17) but markedly increased in $2013(\hat{N}=45)$. For adults, lower-reach $\hat{N}$ ranged from 74 to 303 , while upperreach $\hat{N}$ ranged from 172 to 414 . For summed-reach adults, $\hat{N}$ ranged from 282 to 674 and declined by $58 \%$ over the 5 most recent years (2008 to 2013 ; Fig. 3). Annual adult densities were 0.4 to 1.7 fish $\mathrm{km}^{-1}$ (mean $=1.1$ fish $\mathrm{km}^{-1} ; \mathrm{SE}=0.12$ ) in the lower reach and 1.5 to 3.9 fish $\mathrm{km}^{-1}$ (mean $=2.8$ fish km${ }^{-1}$; $\mathrm{SE}=0.20$ ) in the upper reach.

A standard for accepted $\hat{N}$ precision is a $\mathrm{CV}$ of $\leq 20 \%$ (Pollock et al. 1990). This standard was generally met for upper-reach estimates (excluding juvenile $\hat{N}$ ) but not for lower-reach estimates (Table S5 in the Supplement). For all fish, 9 of 13 annual summedreach estimates had $\mathrm{CVs} \leq 20 \%$ and for summedreach adults, 11 of 13 ; for juveniles, none were $\leq 20 \%$. CVs were highest (lowest precision) during the first 2 yr.

The weighted regression trend analysis for summedreach adult $\hat{N}$ indicated strongest support for the quadratic model (weight $=0.85$ ), little support for the intercept-only model (weight $=0.12$ ), and almost no support for the linear model (weight $=0.03$, Table S6 in the Supplement). Model coefficients suggested a

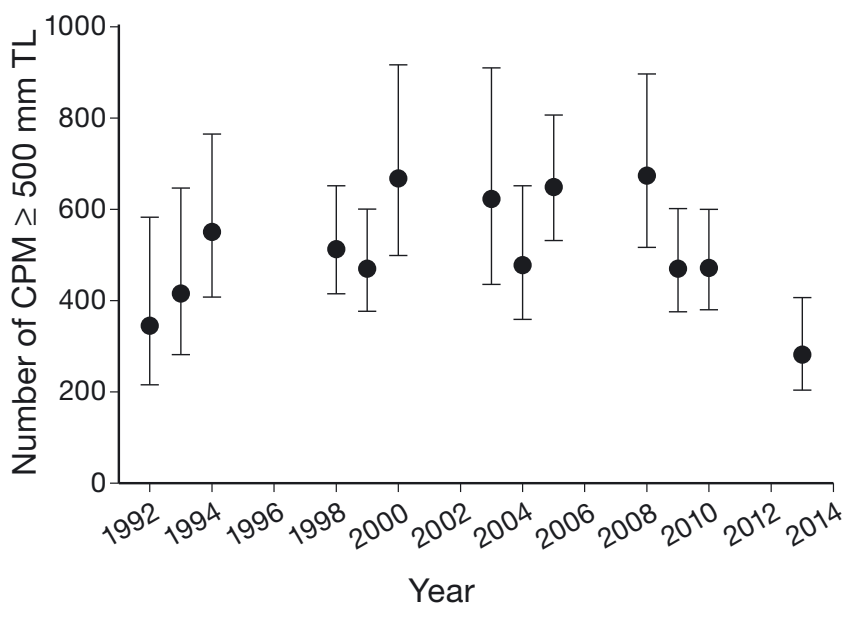

Fig. 3. Abundance estimates of adult ( $\geq 500 \mathrm{~mm}$ total length [TL]) Colorado pikeminnow (CPM) in the Colorado River study area, 1992 to 2013. Annual estimates were derived by summing separate estimates for the lower and upper study reaches. Error bars represent the $95 \%$ CI

significant population increase was followed by a significant decline over the $22 \mathrm{yr}$ period, a trend largely driven by upper-reach adults (quadratic model weight of 0.99 ). For the lower reach, the intercept-only model had highest support (weight of 0.85 ), suggesting adult numbers there were relatively stable. In all cases, linear models had standard errors larger than corresponding coefficients, indicating possible long-term increases or decreases were nonsignificant. 


\section{Dispersal}

During the entire study, only 6 individuals $<400 \mathrm{~mm}$ TL were captured in the upper reach, indicating that few Colorado pikeminnow were reared there. Populating the upper reach required dispersal from the lower-reach nursery area. Consistent with this, most between-reach movements were in an upstream direction. We documented 65 lower- to upper-reach movements and 11 upper- to lower-reach movements. Of 14 individuals that moved upstream and had capture-recapture events spaced 1 yr apart, all moved while $>400 \mathrm{~mm}$ TL (smallest: $402 \mathrm{~mm}$ ), and 10 of these moved while $<500 \mathrm{~mm}$ TL (Table S7 in the Supplement).

\section{Length frequency}

Because most upstream migrants were relatively young, pulses of upstream migration resulted in periodic increases of sub- and young adults in the upper reach. Fish $<500 \mathrm{~mm}$ TL comprised $\geq 15 \%$ of upperreach samples only during 1993, 1994, and 2005.

Large adults comprised an increasing percentage of samples over time. In the lower reach, those $\geq 650 \mathrm{~mm}$ TL were 0 to $2 \%$ during 1991 to 1994 but were $8 \%$ by 2013 . Very large adults ( $\geq 800 \mathrm{~mm}$ TL) were rare there, with only 6 captured. In the upper reach, percentages of individuals $\geq 650 \mathrm{~mm}$ TL were similar during 1991 to 2000 (24 to $36 \%$ ) but markedly increased during 2003 to 2013 (46 to $66 \%$ ), ostensibly from growth of a strong 1986 year class (see next subsection). Frequency of very large adults also increased in the upper reach. By 2013, those $\geq 800 \mathrm{~mm}$ TL comprised $20 \%$ of the sampled population.

Two temporary declines in median length of upperreach fish suggest that only 2 strong year classes (1986 and 1998) occurred with origins between 1985 and 2006. The first decline occurred in the early 1990s, when substantial numbers of sub- and young adults dispersed upstream (Fig. 4). By 1998, median length had increased, indicating that upstream dispersal had diminished. After cresting at $680 \mathrm{~mm}$ in 2004, median length again decreased in 2005 after a second strong cohort dispersed upstream. After 2008, median length increased as fish aged.

\section{Relative year-class strength}

In 1991, estimated age 5 fish made up $76 \%$ of the lower-reach sample, making the 1986 year class the

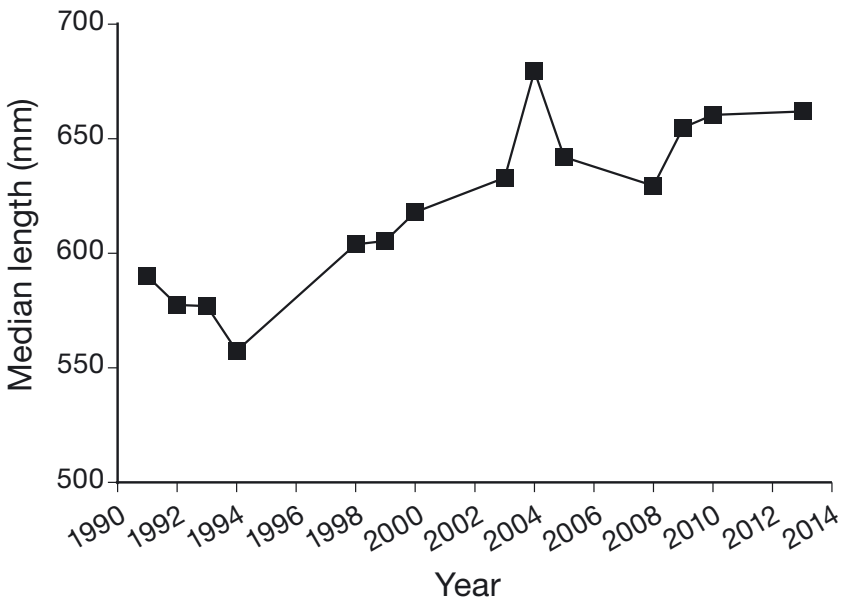

Fig. 4. Median lengths of Colorado pikeminnow captured in the upper study reach, 1991 to 2013

strongest of the study. The 1998 year class was also strong (64\%) at age 5 (Table 2). In addition, a large number of fish estimated as age 6 were captured in 2013. These comprised 54 or $63 \%$ of the sample (depending on exclusion or inclusion, respectively, of 8 possible age 5 fish), indicating a strong 2007 year class. From our analysis of lower-reach age classes, we estimated 14 weak, 6 moderately strong, and 3 strong year classes were produced over 23 yr (1986 to 2008).

\section{Relation of age 5 to age 0 year-class strength}

From 1986 to 2013, mean CPE of lower-reach YOY was relatively high in 3 years: 1986, 1996, and 2009 (Fig. 5). All 9 yr from 1987 through 1995 had moderate catch rates of YOY. After 1996, mean CPE was often substantially reduced. It was strong in $1 \mathrm{yr}$ (2009), of moderate strength in $3 \mathrm{yr}$, and weak in 13 yr. No YOY were captured in 2003 and 2008.

Fall YOY CPE was not always a useful predictor of later strength at age 5. The 1996 year class began strong but essentially disappeared by age 5 . Of 9 moderately strong year classes produced during 1986 to 1995,4 remained moderately strong and 5 became weak. From 1997 through 2008, 1 year class began and remained moderately strong, 8 began and remained weak, 1 began weak but became moderately strong, and 2 began weak but were strong by age 5 or 6. For more recent cohorts (2009 to 2013), strength at age 5 could not yet be assessed. Of 23 year classes with strength assessments available for both life stages, strength was consistent 14 times and inconsistent 9 times (Table 3). The null hypothesis of inde- 
Table 2. Qualitative estimates of Colorado pikeminnow year-class strength based on length-frequency histograms of samples collected from the Colorado River lower-reach study area. Strength of each age 5 cohort is based on percentage of total sample collected. Weak: 0 to $15 \%$; moderate: 16 to $50 \%$; strong: 51 to $100 \%$. Dashes indicate years in which no sampling for age 5 fish was done

\begin{tabular}{|c|c|c|c|c|c|c|c|}
\hline $\begin{array}{l}\text { Year of } \\
\text { origin }\end{array}$ & $\begin{array}{c}\text { Length- } \\
\text { frequency } \\
\text { year }\end{array}$ & $\begin{array}{l}\text { Length } \\
\text { range age } 5 \\
(\mathrm{~mm})\end{array}$ & $\begin{array}{c}\text { Number } \\
\text { in age } 5 \\
\text { group }\end{array}$ & $\begin{array}{l}\text { Lower-reach } \\
\text { sample } \\
\text { (n) }\end{array}$ & $\begin{array}{c}\text { Age } 5 \\
\text { (\% of total) }\end{array}$ & $\begin{array}{c}\text { Mean length } \\
\text { age } 5 \\
(\mathrm{~mm})\end{array}$ & $\begin{array}{c}\text { Year- } \\
\text { class } \\
\text { strength }\end{array}$ \\
\hline 1986 & 1991 & $325-401$ & 28 & 37 & 76 & 363 & Strong \\
\hline 1987 & 1992 & $320-380$ & 6 & 32 & 19 & 365 & Moderate \\
\hline 1988 & 1993 & $345-416$ & 5 & 88 & 6 & 382 & Weak \\
\hline 1989 & 1994 & $353-446$ & 8 & 66 & 12 & 386 & Weak \\
\hline 1990 & 1995 & - & - & - & - & - & Weak $^{\mathrm{a}}$ \\
\hline 1991 & 1996 & - & - & - & - & - & Moderate $^{b}$ \\
\hline 1992 & 1997 & - & - & - & - & - & Moderate \\
\hline 1993 & 1998 & $334-389$ & 15 & 86 & 17 & 365 & Moderate \\
\hline 1994 & 1999 & $343-382$ & 5 & 60 & 8 & 360 & Weak \\
\hline 1995 & 2000 & $400-420$ & 3 & 49 & 6 & 412 & Weak \\
\hline 1996 & 2001 & - & - & - & - & - & Weak $^{\mathrm{d}}$ \\
\hline 1997 & 2002 & - & - & - & - & - & Weak ${ }^{\mathrm{e}}$ \\
\hline 1998 & 2003 & $325-435$ & 70 & 109 & 64 & 387 & Strong \\
\hline 1999 & 2004 & $347-411$ & 11 & 110 & 10 & 387 & Weak \\
\hline 2000 & 2005 & $334-432$ & 24 & 143 & 17 & 374 & Moderate \\
\hline 2001 & 2006 & - & - & - & - & - & Weak $^{\mathrm{f}}$ \\
\hline 2002 & 2007 & - & - & - & - & - & Weak $^{g}$ \\
\hline 2003 & 2008 & $397-442$ & 6 & 89 & 7 & 416 & Weak \\
\hline 2004 & 2009 & $374-448$ & 4 & 81 & 5 & 409 & Weak \\
\hline 2005 & 2010 & $327-409$ & 25 & 92 & 27 & 367 & Moderate \\
\hline 2006 & 2011 & - & - & - & - & - & Weak $^{\mathrm{h}}$ \\
\hline 2007 & 2012 & - & - & - & - & - & Strong ${ }^{i}$ \\
\hline 2008 & 2013 & $343-387$ & 8 & 76 & 11 & 375 & Weak \\
\hline \multicolumn{8}{|c|}{ 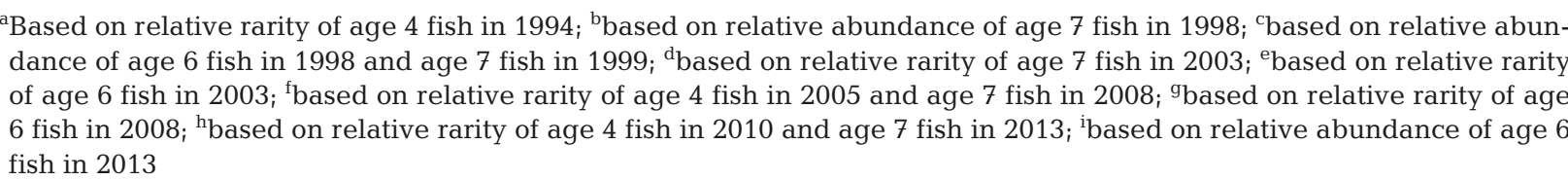 } \\
\hline
\end{tabular}

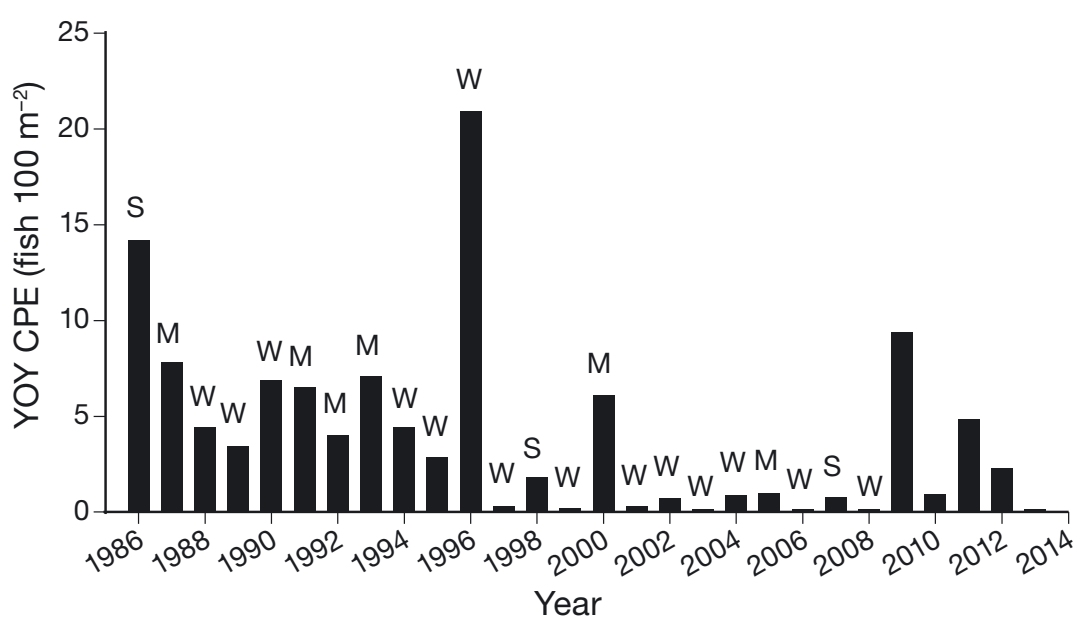

Fig. 5. Catch per effort (CPE) of young-of-the-year (YOY) Colorado pikeminnow seined from lower-reach backwaters, 1986 to 2013 (Harding et al. 2013), and later strength (S: strong; M: moderate; W: weak) of the corresponding year class at ages 4 to 6 (see Table 2). Later strength could not yet be assessed for year classes 2009 to 2013 pendence between strength at the 2 life stages could not be rejected $(\mathrm{p}=$ 0.0751). Of 9 possible outcome combinations, a weak year class remaining weak had the highest probability (73.0\%; $95 \% \mathrm{CI}=0.43$ to 0.92 ).

\section{Intersystem movements}

We documented 70 intersystem movements from 1991 to 2013. To do so, a fish must have been captured at least once in each river. By the end of 2013, 860 individuals first tagged in the CRS and 2761 individuals first tagged in the GRS had been recaptured at least once. Of these, 1.73\% made at least 1 intersystem movement. 
Table 3. Estimated probabilities of possible outcomes (later year-class strength) from frequency of observed outcomes for each of 3 age 0 yearclass strength categories (weak, moderate, strong) in the lower-reach study area, 1986 to 2008. Fall young-of-the-year seining catch rate (Harding et al. 2013) was used to assess strength at age 0, and relative abundance in length-frequency histograms (present study) was used to assess year-class strength at age 5 (or age 4 or 6 ). Also provided are SE and $95 \%$ CI

\begin{tabular}{|lccccc|}
\hline Age 0 & Ages 4-6 & $\begin{array}{c}\text { No. of obs. } \\
\text { outcomes }\end{array}$ & $\begin{array}{c}\text { Estimated } \\
\text { probability }\end{array}$ & SE & $95 \%$ CI \\
\hline Weak & Weak & 8 & 0.727 & 0.134 & $0.435-0.924$ \\
Weak & Moderate & 1 & 0.091 & 0.087 & $0.005-0.344$ \\
Weak & Strong & 2 & 0.182 & 0.116 & $0.033-0.464$ \\
Moderate & Weak & 5 & 0.500 & 0.158 & $0.217-0.783$ \\
Moderate & Moderate & 5 & 0.500 & 0.158 & $0.217-0.783$ \\
Moderate & Strong & 0 & 0.000 & 0.000 & $0.000-0.000$ \\
Strong & Weak & 1 & 0.500 & 0.354 & $0.038-0.962$ \\
Strong & Moderate & 0 & 0.000 & 0.000 & $0.000-0.000$ \\
Strong & Strong & 1 & 0.500 & 0.354 & $0.038-0.962$ \\
\hline
\end{tabular}

post-stocking. Stocked fish captures were not included in our capture history matrices or analyses of wild fish.

\section{Fish ladder captures}

From 1996 through 2013, 124 wild Colorado pikeminnow (105 unique fish) were captured while ascending the Gunnison River via the Redlands Diversion Dam ladder, yet few apparently remained upstream of the dam. Twenty-two (21\%) were subsequently captured downstream of the ladder, mostly in the Colorado River. Two of 3 captured upstream of the ladder were later captured downstream. During 6 Gunnison River dual-shore electrofishing surveys (2011 to 2013) from

Thirty-five individuals tagged in the CRS moved to the GRS, 6 of which later returned. Twenty-eight tagged in the GRS moved to the CRS, 1 of which later returned. Of 2104 unique fish captured in the CRS, $1.33 \%$ had previously been tagged in the GRS, and of 8722 captured in the GRS, $0.40 \%$ had previously been tagged in the CRS. Rate of detected movements from the GRS to the CRS over $22 \mathrm{yr}$ averaged 1.3 fish $\mathrm{yr}^{-1}$. Using a mean annual capture probability of 0.20 (Table 1), estimated total movements from the Green

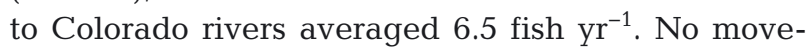
ment of Colorado pikeminnow between the San Juan River and Colorado or Green rivers (across Lake Powell) has ever been documented.

\section{Captures of stocked Colorado pikeminnow}

A total of 5084 hatchery-reared, PIT-tagged Colorado pikeminnow (mean length $=213 \mathrm{~mm}$ ) were stocked in the Gunnison and Colorado rivers upstream of our study area in 2003 and 2004 by Colorado Parks and Wildlife and the USFWS. None of the 2069 fish stocked in 2003 were later recaptured. Two 2004-stocked fish were captured during our lower-reach sampling in 2004. In 2005, 45 more were captured (including 5 captured twice): 9 from the upper reach and 36 from the lower reach. Using mark-recapture, 190 were estimated still present in 2005 , or $3.7 \%$ of those stocked. Four were captured in 2008, 1 of which was recaptured in 2010. No others were captured through 2013. Using annual $\hat{p}$ of lower-reach wild fish in 2008 (0.23; Table 1), 17 hatchery fish $(0.3 \%)$ were estimated present 4 to $5 \mathrm{yr}$
Delta, Colorado, to the dam (86 km), only 1 Colorado pikeminnow was captured, and it had only recently ascended the ladder (USFWS unpubl. data). On the Colorado River, fish trap monitoring through 2013 at the most upstream ladder yielded no Colorado pikeminnow since access to the ladder was provided in 2008.

\section{DISCUSSION}

Our monitoring of a sparse but well-distributed fish population in a mid-sized turbid river demonstrated that obtaining useful abundance estimates with mark-recapture techniques was feasible, though only barely so. Wide $\hat{N}$ confidence intervals, resulting from low capture probabilities, made assessing abundance trends difficult. With an overall mean $p$ of only 0.064 pass $^{-1}$ and $0.200 \mathrm{yr}^{-1}$, we were able to detect a significant $(p<0.05)$ decline in adult abundance but only when estimates declined by over $50 \%$.

This study provided many insights into the demographic dynamics of a small Colorado pikeminnow population, allowing us to meet our 4 objectives: (1) adult abundance and survival-rate estimates revealed status and trends, (2) dispersal patterns and juvenile length frequencies indicated recruitment occurred in infrequent pulses, (3) temporal changes in cohort strength demonstrated variable juvenile mortality affecting recruitment dynamics, and (4) movement rates between the Green and Colorado rivers were small and appeared balanced. 
Our results also demonstrate the importance of long-term monitoring. After the first $17 \mathrm{yr}$ (1992 to 2008), an assessment of population trend would have concluded the population was progressing toward recovery. However, monitoring an additional 5 yr revealed a steep decline in adult abundance. By 2013, $\hat{N}$ was $18 \%$ lower than in 1992. Increased median length and higher frequencies of large adults from 1998 to 2013 revealed a steadily aging population.

The earlier identification of low recruitment rate as the process most limiting this population (e.g. Osmundson \& Burnham 1998) was reinforced by additional years of data. Year classes were often weak, with most recruitment a result of rare strong year classes. During 23 yr, only 3 strong cohorts were detected. Study initiation coincided with recruitment of the largest cohort, resulting in an upward population trend. After 2000, the decline in adults was driven by a series of weak recruiting cohorts that failed to counteract mortality.

A rapid population decline similarly occurred in the Green River when adult estimates dropped by $48 \%$ in $4 \mathrm{yr}$, a decline attributed to low recruitment and significantly reduced adult survival (Bestgen et al. 2007). In the Colorado River, recruitment failure alone appears responsible for the recent decline. Assuming $15 \%$ annual mortality, no recruitment would result in a $56 \%$ reduction in $5 \mathrm{yr}$, similar to the $58 \%$ reduction we estimated. In the short term, another strong year class could reverse this decline. In the long term, a consistently higher frequency of strong year classes will be needed to assure population recovery.

Survival rate was relatively high and was probably fairly constant within matrix periods because the top models indicated no time effect on $S$. Estimates of $S$ were higher in the upper reach than in the lower reach, suggesting, in part, more suitable upper-reach habitat. The predominance of upstream movements, higher densities, and greater upper-reach mean adult body condition supports this (Osmundson et al. 1998).

Although YOY density in fall provides an initial index to year-class strength, it proved an unreliable predictor of later strength. However, because weak year classes had a high probability of remaining weak, the high and increasing frequency of weak year classes at age 0 from 1997 through 2013 (13 of 17 yr) does not bode well for this population's near-term future. Any management efforts that enhance YOY production should be given high priority.

Exchange of individuals with the Green River population involved a very small fraction of each popula- tion but may have important genetic implications. Although between-river movements do not guarantee gene flow, it is reasonable to assume some migrants stayed and spawned in the neighboring river. To ensure beneficial genetic connectivity, Mills \& Allendorf (1996) recommended 1 to 10 migrants per generation, a standard that was probably met here.

The 2 systems function as a metapopulation, i.e. having discreet breeding populations connected by migration, such that recolonization is possible, affecting long-term metapopulation dynamics, but with an exchange rate so low that migration has negligible effect on local short-term population dynamics (Hanski \& Simberloff 1997). Thus, these 2 groups presumably represent the remnant of a once extensive metapopulation that occurred prior to range fragmentation and loss of tributary populations.

Population abundance criteria for the Colorado River sub-basin call for each of 5 consecutive annual point estimates to exceed 700 adults (along with additional criteria being met for the Green and San Juan sub-basins) before downlisting can be considered (USFWS 2002). No 5 yr period during our 22 yr of monitoring met this criterion. Although this population continued to persist, an achievement worth noting, no progress toward recovery was evident based on demographic trends.

\section{Recruitment limitations}

Understanding why this population has declined to such low levels requires some background information and a brief description of factors possibly hindering recruitment. Though speculative and not allencompassing, our hope is to provide a starting point for future discussions of research needs.

Fish life strategies evolve to cope with and thrive under the extreme environmental variation that predictably recurs annually in the temperate zone (Conover 1992, Gasith \& Resh 1999). In the upper Colorado River basin, flow conditions are largely driven by snowpack. Droughts may hamper reproductive success, and floods or winter ice conditions may increase mortality of young. High fecundity and long life are traits of Colorado pikeminnow that aid population persistence through periods of low recruitment (Tyus 1986, Osmundson 2006). Such species, termed periodic strategists, are characterized by large size, late maturation, high fecundity, and long generation times (Winemiller 2005). Periodic recruitment can result in unusually strong cohorts that may dominate the adult population for many years, as was 
observed here. Though such variable recruitment might therefore be expected, a reduced frequency of years with conditions favorable for reproduction and early life survival may have led to insufficient longterm recruitment rates.

Recruitment is the outcome of 2 main processes: (1) successful reproduction and egg incubation resulting in abundant emerging larvae, and (2) survival of young to the adult phase. Each of these processes can be partitioned into various stages or sub-processes. Green River studies have contributed much to our knowledge of Colorado pikeminnow early life history. There, reproductive success is monitored annually with larval drift net sampling downstream of 2 major spawning areas. Variable production of YOY has been linked to flow regime, with larval production influenced by spring flow magnitude and larval survival influenced by availability of stable, quality nursery habitat (Bestgen \& Hill 2016). Green River backwater nursery habitat is maximized in years with moderate summer-fall base flows (Grand et al. 2006). Although factors affecting recruitment processes likely differ in the 2 systems due to geomorphic and water regulation differences, Green River investigations offer important insights regarding flow effects on recruitment rate. Flow effects on reproductive success in the Colorado River are not well understood because larval production is not monitored.

If larval drift studies implicate limited reproductive success, controlled experiments will be needed to identify underlying causes. In various regulated western rivers, reproductive failure of white sturgeon Acipenser transmontanus, another highly fecund species that broadcast spawns during the declining limb of the spring hydrograph, has been successfully linked to degraded substrate conditions (McAdam et al. 2005, Paragamian 2012, Crossman \& Hildebrand 2014, McAdam 2015). In the Colorado River, many headwater dams have cumulatively reduced spring discharge such that flows capable of flushing fine sediments and resorting streambed particles have become much less frequent. In our upper-reach study area, the mean recurrence interval of peak flows sufficient to mobilize cobble on a widespread basis $\left(650 \mathrm{~m}^{3} \mathrm{~s}^{-1}\right)$ has lengthened following river regulation from 1.4-2.7 yr (depending on stratum) to 4.6$13.5 \mathrm{yr}$ (Osmundson et al. 2002). Although cobble substrates are always present, depth of interstitial voids for egg deposition and incubation may be ideal for spawning only after the occasional big flow event. McAda \& Ryel (1999) reported YOY Colorado pikeminnow were most abundant in years with moderate peak and base flows preceded by a year of very high spring runoff. Similar analyses are needed to substantiate this observation using the longer time series data now available.

Effects of waterborne contaminants on pikeminnow reproductive physiology are currently unknown. Our upper study reach, a concentration area for adults, bisects an agricultural and urban area where elevated levels of selenium, pesticides, mercury, and endocrine-modulating chemicals have been identified in drain waters entering the river (Osmundson et al. 2000, Hinck et al. 2007).

Spring runoff in May and June might displace many juveniles far downstream, a dispersal mechanism under more natural conditions. Today, displaced juveniles may be subjected to intense predation from sport fish in downstream Lake Powell (Persons \& Bulkley 1982). By late 2013, drought had caused the lake inflow to recede some $63 \mathrm{~km}$ downstream. This increased separation between nursery area and reservoir might benefit juvenile survival. Sampling of juveniles in this newly uncovered river reach would help determine the extent of downstream displacement and resolve whether the reservoir acts as a sink for juveniles.

Densities of predacious non-native fishes in the river itself have increased in recent years. Smallmouth bass Micropterus dolomieu proliferated throughout our upper study area beginning in 2003. In 2010, an invasion by walleye Sander vitreus in the lowerreach nursery area added a new and possibly irreversible source of juvenile mortality, as well as competition for pikeminnow adults. By 2013, captures of lower-reach walleye were 3.7 times those of Colorado pikeminnow. Although these new actors additionally threaten recruitment rates and recovery, we emphasize that Colorado pikeminnow YOY densities were already reduced prior to their arrival.

\section{Recovery efforts}

The Recovery Program, formed in 1987, oversees recovery efforts for Colorado pikeminnow and 3 other endangered upper Colorado River basin fish species. Representatives from federal and state agencies, environmental groups, and water and power stakeholders prioritize and fund research, monitoring, information and education, and flow and nonflow management actions. The program's over-arching premise is that recovery can be achieved while allowing water development within the basin to proceed, pursuant to state water law and interstate com- 
pacts (i.e. implementing the program acts as mitigation for water withdrawals). The goal at inception was to recover the 4 species in 15 yr (Wydoski \& Hamill 1991). Managers today struggle to define what is biologically needed to assure long-term selfsustainability while devising and implementing actions that can reasonably be done within budgetary and societal constraints (Valdez \& Muth 2005).

Our results indicate that the Colorado River population of Colorado pikeminnow has not recovered after 25 yr of Recovery Program implementation. Strong recruitment in the early 1990s that most contributed to increased abundance during our study was from a cohort produced prior to establishment of the Recovery Program. Recovery efforts to date have emphasized upstream range expansion (fish ladders and stocking), mechanical removal of non-native fish, and augmentation of summer base flows in an upstream reach impacted by summer irrigation diversions (USFWS 2015).

Efforts to expand Colorado pikeminnow range upstream of the study area were mostly unsuccessful. No fish stocked there were subsequently detected, despite extensive sampling (USFWS unpubl. data). Although 124 wild Colorado pikeminnow used the Gunnison River fish ladder, few apparently remained upstream, suggesting unsuitable habitat conditions there. On the Colorado River mainstem, no wild or stocked individuals ascended the most upstream fish ladder during $5 \mathrm{yr}$ of operation. Upstream dispersal and colonization, anticipated by recovery planners (e.g. Valdez \& Muth 2005), have yet to materialize.

Unsuitable thermal conditions have probably long precluded upstream range expansion in the Colorado River mainstem (Osmundson 2011), but frequent use of the Gunnison River fish ladder demonstrates the potential of this once occupied tributary. Reregulation of upstream federal dams on the Gunnison has only recently begun. If spring releases are robust and frequent, it is hoped conditions can be restored that support and retain colonists from the Colorado River. Historic records (Jordan \& Evermann 1896) and anecdotal accounts (Quarterone 1993) indicate that Colorado pikeminnow once flourished upstream to Delta, Colorado (Gunnison rkm 91), as recently as the 1950s, leading to a critical habitat designation for this reach. Tributary recolonization would provide greater spatial structure of the larger population, increasing population viability. Such increased representation across historical range protects local adaptations and reduces risk of widespread loss from localized catastrophes (e.g. Lindley et al. 2007, Redford et al. 2011).
Augmentation of summer base flows through reservoir releases has helped prevent dewatering of upstream reaches important to adults. Additionally, efforts to control non-native fish through mechanical removal (electrofishing) aim to decrease competition and predation on native fishes (but see Zelasko et al. 2016).

Base flow augmentation, reduction of competition, and range expansion are designed to increase the system's carrying capacity, which ultimately delimits the potential for population increase (Lande 1993). These efforts, though important, have a low probability of success without first placing a greater emphasis on actions that enhance recruitment, the process identified as currently limiting (e.g. Osmundson \& Burnham 1998, present study).

Coordinating releases from upstream Colorado River reservoirs during spring runoff is, in concept, the best attempt by the Recovery Program to improve habitat, including spawning conditions. Initiated in 1997, the program aims to augment habitat-forming peak flows, with releases made in 10 of the past $20 \mathrm{yr}$. However, even with the program, the frequency of years with peak flows capable of mobilizing coarse substrates throughout our upper study area has declined from $30 \%$ during the prior $20 \mathrm{yr}$ (1976 to 1996) to $25 \%$ in more recent years. A higher frequency of such years has long been recommended to improve endangered fish habitat (e.g. Osmundson \& Kaeding 1991, Osmundson et al. 1995, 2002, Pitlick \& Van Steeter 1998, Van Steeter \& Pitlick 1998).

With already tight water supplies, a warming climate trend, and increasing demands for water, the voluntary participation by dam operators to release fish flows may diminish over time, limiting future peak flow augmentation opportunities. If larval production is proved limited by substrate conditions, artificial placement of spawning materials could be considered. Spawning reefs developed for white sturgeon have successfully benefited reproduction and recruitment in eastern US rivers (e.g. Dumont et al. 2011, Roseman et al. 2011). For this and other conservation-reliant species, sustained habitat management efforts may prove the only realistic option for maintaining wild populations (Doremus \& Pagel 2001, Bocetti et al. 2012).

The decline of this species has largely been a story of range reduction, a process that continues today. Remnant wild populations in the Gunnison and San Juan rivers have become extirpated, and a relatively robust Yampa River subpopulation has declined substantially in recent years (Johnson et al. 2008, Zelasko et al. 2016, Bestgen et al. 2017). Persistence of 
self-sustaining populations in the Colorado and Green rivers will be contingent on researchers identifying factors limiting recruitment and the ability of managers to effectively address those factors. Several lines of possible inquiry for future Colorado River investigators include assessing (1) reproductive success using larval drift net sampling, (2) the role of substrate suitability on reproductive success, (3) contaminant effects on reproduction and larval survival, and (4) larval and YOY losses to downstream Lake Powell. An adaptive management approach (e.g. Walters 1986, Runge 2011) is now needed to identify, prioritize, and initiate critically needed research so future recovery actions can better target recruitment limitations.

\section{CONCLUSIONS}

Long-term mark-recapture monitoring can provide important insights into riverine fish demography. Estimates of numerical abundance greatly improve understanding of population status over more typical $\mathrm{CPE}$ indices. Though requiring a substantial commitment of resources, knowledge of abundance, recruitment, migration, and adult survival rate is critically needed by managers charged with restoring imperiled freshwater fish. Efficacy of recovery actions can only be reliably assessed by the demographic responses of fish populations (Budy \& Schaller 2007). In addition, large capture history data sets provide much-needed ancillary data that help fill knowledge gaps of life history traits often lacking for endangered taxa (i.e. growth, dispersal, age at first reproduction, sex ratio, generation time; Cooke et al. 2012, Chasco et al. 2014). For long-lived fish, our results suggest that the duration of monitoring periods for down- or delisting consideration should be based on the temporal variation in abundance revealed by long-term studies. Finally, unless fish are seasonally concentrated in known habitats or are especially vulnerable to capture methods, mark-recapture applications in very large rivers may not be practical. Investigators in other systems are encouraged to perform pilot studies to estimate capture probability before committing to long-term mark-recapture monitoring (Al-Chokhachy et al. 2009).

Acknowledgements. We thank the many individuals that provided field and administrative assistance. Bob Burdick shared capture records from his smallmouth bass removal and fish ladder monitoring projects. Katherine Creighton granted permission to use UDWR YOY monitoring results. Travis Francis provided invaluable assistance in the field and summary data from the upper basin PIT tag database. Brandon Albrecht, Dave Speas, Pete Cavalli, Kevin Bestgen, Katherine Creighton, and 3 anonymous reviewers provided thoughtful comments on earlier drafts. Funding was provided by the USFWS and the Recovery Implementation Program for Endangered Fish Species in the Upper Colorado River Basin. This article reflects the views of the authors and does not necessarily reflect the views of the USFWS.

\section{LITERATURE CITED}

Akaike $H$ (1973) Information theory and an extension of the maximum likelihood principle. In: Petrov BN, Csaki F (eds) Proc 2nd Int Symp Inf Theory, Tsahkadsor, 2-8 Sep 1971. Akademiai Kiado, Budapest, p 267-281

Al-Chokhachy R, Budy P, Conner M (2009) Detecting declines in the abundance of a bull trout (Salvelinus confluentus) population: understanding the accuracy, precision, and costs of our efforts. Can J Fish Aquat Sci 66:649-658

Anderson RO, Gutreuter SJ (1983) Length, weight, and structural indices. In: Nielsen LA, Johnson DL (eds) Fisheries techniques. American Fisheries Society, Bethesda, MD, p 283-300

Bestgen KR, Hill AA (2016) Reproduction, abundance, and recruitment dynamics of young Colorado pikeminnow in the Green and Yampa rivers, Utah and Colorado, 19792012. Final report. Larval Fish Laboratory, Colorado State University, Fort Collins, CO

Bestgen KR, Hawkins JA, White GC, Christopherson KD and others (2007) Population status of Colorado pikeminnow in the Green River basin, Utah and Colorado. Trans Am Fish Soc 136:1356-1380

Bestgen KR, Hawkins JA, White GC, Walford CD, Badame P, Monroe L (2010) Population status of Colorado pikeminnow in the Green River basin, Utah and Colorado, 2006-2008. Larval Fish Laboratory, Colorado State University, Fort Collins, CO

Bestgen KR, Walford CD, White GC, Hawkins JA and others (2017) Population status of Colorado pikeminnow in the Green River basin, Utah and Colorado, 2000-2013. Final report. Larval Fish Laboratory, Colorado State University, Fort Collins, CO

*Bocetti CI, Goble DD, Scott JM (2012) Using conservation management agreements to secure postrecovery perpetuation of conservation-reliant species: the Kirtland's warbler as a case study. Bioscience 62:874-879

*Bdy P, Schaller H (2007) Evaluating tributary restoration potential for Pacific salmon recovery. Ecol Appl 17: 1068-1086

* Carroll R, Augspurger C, Dobson A, Franklin J and others (1996) Strengthening the use of science in achieving the goals of the Endangered Species Act: an assessment by the Ecological Society of America. Ecol Appl 6:1-11

Castello L, Arantes CC, Mcgrath DG, Stewart DJ, Sousa FSD (2015) Understanding fishing-induced extinctions in the Amazon. Aquat Conserv 25:587-598

* Chasco BE, Ward EJ, Hesse JA, Rabe C, Kinzer R, Vogel JL, Orme R (2014) Evaluating the accuracy and precision of multiple abundance estimators using state-space models: a case study for the threatened population of Chinook salmon in Johnson Creek, Idaho. N Am J Fish Manage 34:945-954 
Conover DO (1992) Seasonality and the scheduling of life history at different latitudes. J Fish Biol 41:161-178

* Cooke SJ, Paukert C, Hogan Z (2012) Endangered river fish: factors hindering conservation and restoration. Endang Species Res 17:179-191

Crossman JA, Hildebrand LR (2014) Evaluation of spawning substrate enhancement for white sturgeon in a regulated river: effects on larval retention and dispersal. River Res Appl 30:1-10

* Doremus H, Pagel JE (2001) Why listing may be forever: perspectives on delisting under the US Endangered Species Act. Conserv Biol 15:1258-1268

* Dumont P, D'Amours J, Thibodeau S, Dubuc N and others (2011) Effects of the development of a newly created spawning ground in the Des Prairies River (Quebec, Canada) on the reproductive success of lake sturgeon (Acipenser fulvescens). J Appl Ichthyol 27:394-404

* Durst SL, Franssen NR (2014) Movement and growth of juvenile Colorado pikeminnows in the San Juan River, Colorado, New Mexico, and Utah. Trans Am Fish Soc 143: 519-527

Fieberg J, Ellner SP (2000) When is it meaningful to estimate an extinction probability? Ecology 81:2040-2047

Galat DL, Zweimüller I (2001) Conserving large-river fishes: Is the highway analogy an appropriate paradigm? J N Am Benthol Soc 20:266-279

Gasith A, Resh VH (1999) Streams in Mediterranean climate regions: abiotic influences and biotic responses to predictable events. Annu Rev Ecol Syst 30:51-81

* Gerber LR, DeMaster DP, Kareiva PM (1999) Gray whales and the value of monitoring data in implementing the US Endangered Species Act. Conserv Biol 13:1215-1219

Gibbons JW, Andrews KM (2004) PIT tagging: simple technology at its best. Bioscience 54:447-454

Grand TC, Railsback SF, Hayse JW, LaGory KE (2006) A physical habitat model for predicting the effects of flow fluctuations in nursery habitats of the endangered Colorado pikeminnow (Ptychocheilus lucius). River Res Appl 22:1125-1142

Hanski I, Simberloff D (1997) The metapopulation approach, its history, conceptual domain, and application to conservation. In: Hanski I, Gilpin ME (eds) Metapopulation biology, ecology, genetics, and evolution. Academic Press, San Diego, CA, p 5-26

Harding I, Breen MJ, Skorupski A, Michaud CM, Creighton KL (2013) Annual fall monitoring of young of year Colorado pikeminnow and small-bodied native fish. Annual Progress Report FY 2013. Utah Division of Wildlife Resources, Salt Lake City, UT

Hinck JE, Blazer VS, Denslow ND, Echols KR and others (2007) Chemical contaminants, health indicators, and reproductive biomarker responses in fish from the Colorado River and its tributaries. Sci Total Environ 378:376-402

Holden PB (2000) Program evaluation report for the 7 -year research period (1991-1997). San Juan River Basin Recovery Implementation Program, US Fish and Wildlife Service, Albuquerque, NM

Holden PB, Stalnaker CB (1975) Distribution and abundance of mainstream fishes of the middle and upper Colorado River basins, 1967-1973. Trans Am Fish Soc 104:217-231

Huggins RM (1989) On the statistical analysis of capturerecapture experiments. Biometrika 76:133-140

Huggins RM (1991) Some practical aspects of a conditional likelihood approach to capture experiments. Biometrics
47:725-732

Jelks HL, Walsh SJ, Burkhead NM, Contreras-Balderas S and others (2008) Conservation status of imperiled North American freshwater and diadromous fishes. Fisheries 33:372-407

Johnson BM, Martinez PJ, Hawkins JA, Bestgen KR (2008) Ranking predatory threats by nonnative fishes in the Yampa River, Colorado, via bioenergetics modeling. N Am J Fish Manage 28:1941-1953

Jordan DS, Evermann BW (1896) The fishes of North and Middle America. Bull US Natl Mus 47. Government Printing Office, Washington, DC

*Koster WJ (1960) Ptychocheilus lucius (Cyprinidae) in the San Juan River, New Mexico. Southwest Nat 5:174-175

Lande R (1993) Risks of population extinction from demographic and environmental stochasticity and random catastrophes. Am Nat 142:911-927

Lindley ST, Schick RS, Mora E, Adams PB and others (2007) Framework for assessing viability of threatened and endangered Chinook salmon and steelhead in the Sacramento-San Joaquin Basin. San Francisco Estuary Watershed Sci 5:1-26

MacKenzie DI, Nichols JD, Sutton N, Kawanishi K, Baily LL (2005) Improving inferences in population studies of rare species that are detected imperfectly. Ecology 86: 1101-1113

KMcAda CW, Kaeding LR (1991) Movements of adult Colorado squawfish during the spawning season in the upper Colorado River. Trans Am Fish Soc 120:339-345

McAda CW, Ryel RJ (1999) Distribution, relative abundance, and environmental correlates for age-0 Colorado pikeminnow and sympatric fishes in the Colorado River. Final report. US Fish and Wildlife Service, Grand Junction, CO

McAda CW, Bates JW, Cranney JS, Chart TE, Elmblad WR, Nesler TP (1994) Interagency standardized monitoring program: summary of results, 1986-1992. Final report. US Fish and Wildlife Service, Denver, CO

McAdam DSO (2015) Retrospective weight-of-evidence analysis identifies substrate change as the apparent cause of recruitment failure in the upper Columbia River white sturgeon (Acipenser transmontanus). Can J Fish Aquat Sci 72:1208-1220

McAdam SO (2011) Effects of substrate condition on habitat use and survival by white sturgeon (Acipenser transmontanus) larvae and potential implications for recruitment. Can J Fish Aquat Sci 68:812-822

McAdam SO, Walters CJ, Nistor C (2005) Linkages between white sturgeon recruitment and altered bed substrates in the Nechako River, Canada. Trans Am Fish Soc 134: 1448-1456

*McMahon CR, Hindell MA, Burton HR, Bester MN (2005) Comparison of southern elephant seal populations, and observations of a population on a demographic knifeedge. Mar Ecol Prog Ser 288:273-283

Miller RR (1958) Origin and affinities of the freshwater fish fauna of western North America. In: Hubbs CL (ed) Zoogeography. Pub 51. American Association for the Advancement of Science, Washington, DC, p 187-222

Miller RR (1961) Man and the changing fish fauna of the American Southwest. Pap Mich Acad Sci Arts Let 46: 365-404

Mills LS, Allendorf FW (1996) The one-migrant-pergeneration rule in conservation and management. Conserv Biol 10:1509-1518 
Minckley WL (1973) Fishes of Arizona. Arizona Game and Fish Department, Phoenix, AZ

Moyle PB (1976) Inland fishes of California. University of California Press, Berkeley, CA

Mueller GA, Marsh PC (2002) Lost, a desert river and its native fishes: a historical perspective of the lower Colorado River. Inf Technol Rep USGS/BRD/ITR-2002-0010. US Government Printing Office, Denver, CO

Osmundson DB (2006) Proximate causes of sexual size dimorphism in Colorado pikeminnow, a long-lived cyprinid. J Fish Biol 68:1563-1588

O Osmundson DB (2011) Thermal regime suitability: assessment of upstream range restoration potential for Colorado pikeminnow, a warmwater endangered fish. River Res Appl 27:706-722

Osmundson DB, Burnham KP (1998) Status and trends of the endangered Colorado squawfish in the upper Colorado River. Trans Am Fish Soc 127:957-970

Osmundson DB, Kaeding LR (1991) Recommendations for flows in the 15-mile reach during October-June for maintenance and enhancement of endangered fish populations in the upper Colorado River. Final report. US Fish and Wildlife Service, Grand Junction, CO

Osmundson DB, Nelson P, Fenton K, Ryden DW (1995) Relationships between flow and rare fish habitat in the '15mile reach' of the upper Colorado River. Final report. US Fish and Wildlife Service, Grand Junction, CO

Osmundson DB, Ryel RJ, Mourning TE (1997) Growth and survival of Colorado squawfish in the upper Colorado River. Trans Am Fish Soc 126:687-698

O Osmundson DB, Ryel RJ, Tucker ME, Burdick BD, Elmblad WR, Chart TE (1998) Dispersal patterns of subadult and adult Colorado squawfish in the upper Colorado River. Trans Am Fish Soc 127:943-956

Osmundson BC, May TW, Osmundson DB (2000) Selenium concentrations in the Colorado pikeminnow (Ptychocheilus lucius): relationship with flows in the upper Colorado River. Arch Environ Contam Toxicol 38:479-485

Osmundson DB, Ryel RJ, Lamarra VL, Pitlick J (2002) Flowsediment-biota relations: implications for river regulation effects on native fish abundance. Ecol Appl 12: 1719-1739

Paragamian VL (2012) Kootenai River white sturgeon: synthesis of two decades of research. Endang Species Res 17:157-167

Persons WR, Bulkley RV (1982) Feeding activity and spawning time of striped bass in the Colorado River inlet, Lake Powell, Utah. N Am Fish Manage 2:403-408

* Pine WE, Allen MS, Dreitz VJ (2001) Population viability of the Gulf of Mexico sturgeon: inferences from capturerecapture and age-structured models. Trans Am Fish Soc 130:1164-1174

*Pine WE, Pollock KH, Hightower JE, Rice JA (2003) A review of tagging methods for estimating fish population size and components of mortality. Fisheries 28:10-23

Pitlick J, Van Steeter MM (1998) Geomorphology and endangered fish habitats of the upper Colorado River: 2 . Linking sediment transport to habitat maintenance. Water Resour Res 34:303-316

Platania SP, Bestgen KR, Moretti MA, Propst DL, Brooks JE (1991) Status of Colorado squawfish and razorback sucker in the San Juan River, Colorado, New Mexico, and Utah. Southwest Nat 36:147-150

Pollock KH (1982) A capture-recapture design robust to un- equal probability of capture. J Wildl Manag 46:752-757

Pollock KH, Nichols JD, Brownie C, Hines JE (1990) Statistical inference for capture-recapture experiments. Wildl Monogr 107:3-97

Quarterone F (1993) Historical accounts of upper Colorado River basin endangered fish. Final report. Colorado Division of Wildlife, Denver, CO

Redford KH, Amato G, Baillie J, Beldomenico P and others (2011) What does it mean to successfully conserve a (vertebrate) species? Bioscience 61:39-48

Roseman EF, Manny B, Boase J, Child M and others (2011) Lake sturgeon response to a spawning reef constructed in the Detroit river. J Appl Ichthyol 27:66-76

Runge MC (2011) An introduction to adaptive management for threatened and endangered species. J Fish Wildl Manag 2:220-233

Ryden DW (2003) An augmentation plan for Colorado pikeminnow in the San Juan River. Final report. US Fish and Wildlife Service, Grand Junction, CO

Ryden DW, Ahlm LA (1996) Observations on the distribution and movements of Colorado squawfish, Ptychocheilus lucius, in the San Juan River, New Mexico, Colorado, and Utah. Southwest Nat 41:161-168

Schenker N, Gentleman JF (2001) Judging the significance of differences by examining the overlap between confidence intervals. Am Stat 55:182-186

Seber GAF (1982) The estimation of animal abundance, 2nd edn. MacMillan, New York, NY

Smith GR, Miller RR, Sable WD (1979) Species relationships among fishes of the genus Gila in the upper Colorado River drainage. In: Linn RM (ed) Proc 1st Conf Sci Res Natl Parks, New Orleans, LA, 9-12 Nov 1976. US Department of Interior, Washington, DC, p 613-623

Snyder DE (1981) Contributions to a guide to the cypriniform fish larvae of the upper Colorado River system in Colorado. US Bureau of Land Management, Denver, CO

Tyus HM (1986) Life strategies in the evolution of the Colorado squawfish (Ptychocheilus lucius). Great Basin Nat 46:656-661

Tyus HM (1991) Ecology and management of Colorado squawfish. In: Minckley WL, Deacon JE (eds) Battle against extinction: native fish management in the American West. University of Arizona Press, Tucson, AZ, p 379-402

USFWS (US Fish and Wildlife Service) (2015) Section 7 consultation, sufficient progress, and historic projects agreement and recovery action plan. Annual report of Upper Colorado River Endangered Fish Recovery Program. US Fish and Wildlife Service, Denver, CO

USFWS (2002) Colorado pikeminnow (Ptychocheilus lucius) recovery goals: amendment and supplement to the Colorado squawfish recovery plan. US Fish and Wildlife Service, Mountain-Prairie Region (6), Denver, CO

Valdez RA, Muth RT (2005) Ecology and conservation of native fishes in the upper Colorado River basin. Am Fish Soc Symp 45:157-204

*Van Steeter MM, Pitlick J (1998) Geomorphology and endangered fish habitats of the upper Colorado River: 1. Historic changes in streamflow, sediment load, and channel morphology. Water Resour Res 34:287-302

Walters CJ (1986) Adaptive management of renewable resources. McMillan, New York, NY

White GC, Brisbin IL (1980) Estimation and comparison of parameters in stochastic growth models for barn owls. 
Growth 44:97-111

White GC, Burnham KP (1999) Program MARK: survival estimation from populations of marked animals. Bird Study 46:S120-S138

White GC, Kendall WL, Barker RJ (2006) Multistate survival models and their extensions in Program MARK. J Wildl Manag 70:1521-1529

Wilcove DS, McMillan M (2005) The class of '67. In: Goble DD, Scott JM, Davis FW (eds) The Endangered Species Act at thirty, Vol 1: renewing the conservation promise. Island Press, Washington, DC, p 45-50

Winemiller KO (2005) Life history strategies, population reg-

Editorial responsibility: Steven Cooke,

Ottawa, Ontario, Canada ulation, and implications for fisheries management. Can J Fish Aquat Sci 62:872-885

Wydoski RS, Hamill J (1991) Evolution of a cooperative recovery program for endangered fishes in the upper Colorado River basin. In: Minckley WL, Deacon JE (eds) Battle against extinction: native fish management in the American West. University of Arizona Press, Tucson, AZ, p 123-139

Zelasko KA, Bestgen KR, Hawkins JA, White GC (2016) Evaluation of a long-term predator removal program: abundance and population dynamics of invasive northern pike in the Yampa River, Colorado. Trans Am Fish Soc 145:1153-1170

Submitted: July 28, 2016; Accepted: May 25, 2017

Proofs received from author(s): July 13, 2017 